\title{
VIEWPOINT Feeding the world and returning half of the agricultural land back to nature
}

Rattan Lal

$E$ arth's total land area is $1.3916 \times 10^{10}$ ha $\left(3.43725 \times 10^{10} \mathrm{ac}\right)$, of which $4.285 \times 10^{8}$ ha $\left(1.0584 \times 10^{9} \mathrm{ac}\right)$ or $3.1 \%$ includes inland water (Knoema 2021). As a share of total land area, agricultural land (cropland and grazing land) is $37.4 \%$, arable land is $11.1 \%$, and forest land is $30.7 \%$ (Knoema 2021). Therefore, total agricultural land area is about $5.04 \times 10^{9}$ ha $\left(1.25 \times 10^{10} \mathrm{ac}\right)$. Some estimates indicate that an additional $5.93 \times 10^{8}$ ha $(1.4647$ $\times 10^{9} \mathrm{ac}$ ) land may be required to feed the projected population of 10 billion by 2050 (Ranganathan et al. 2018). Such excessive human land use, with strong implications for environmental health and biodiversity (Ramankutty et al. 2018), needs a critical and an objective assessment. In the context of a growing and increasingly affluent world population, it is important to objectively assess the land resources needed to meet the food and other critical requirements of humanity.

Prevalence of undernourished people in the world decreased from 826 million to 695 million in 2019 (FAO et al. 2020). However, disruption in the food supply chain by the COVID-19 pandemic increased the prevalence of undernourishment by 82 to 132 million by December of 2020. This number is projected to increase by 17 to 61 million by the end of 2021 and 19 to 60 million by 2030 (FAO et al. 2020). However, the global total cereal grain production increased from $7.36 \times$ $10^{8} \mathrm{t}\left(8.113 \times 10^{8} \mathrm{tn}\right)$ in 1961 to about 3.0 $\times 10^{9} \mathrm{t}\left(3.3 \times 10^{9} \mathrm{tn}\right)$ in 2019 . Despite the increase in population from 3.05 billion in 1961 to 7.67 billion in 2019, the per capita cereal grain production increased from $241 \mathrm{~kg}(531 \mathrm{lb})$ in 1961 to $388 \mathrm{~kg}$ (855 lb) in 2019 (table 1).

Therefore, the prevalence of undernourishment (i.e., 695 million) increased by 82 to 132 million by 2020 because of the disruptions in food production and supply chains by the COVID-19 pandemic. The latter has disrupted the livelihood of 1.7 billion people (Laishram 2020). Thus, food insecurity is not due to low global cereal grain production but due to other social, economic, political, and human dimension factors. Hunger persists not because of low production but because of lack of access to food due to poverty, civil strife, and political unrest. Hence, the best strategy is not to expand the land area under agricultural production but to use prudently what is produced and return some of the agriculturally marginal land back to nature. Therefore, the objective of this article is to deliberate strategies on how, how much, and by when some of the land now under agriculture can be returned back to nature.

\section{POPULATION GROWTH AND HUNGER HOTSPOTS}

Food availability is unequally distributed geographically. There are hunger hotspots that need an immediate and a long-lasting solution. For example, Africa, and especially sub-Saharan Africa (SSA), is the population hotspot of the world. Its population was merely 0.11 billion in 1800 , 0.13 billion in $1900,0.22$ billion in 1950 , 0.28 billion in $1960,0.48$ billion in 1980 , and 0.81 billion in 2000 . Its current population of 1.3 billion is projected to increase to 1.7 billion by $2030,2.1$ billion by 2040 , 2.5 billion by 2050 , and 4.4 billion by 2100 (UN 2019). Over the period of 300 years (1800 to 2100), the population of Africa would increase from 0.1 billion to 4.4 billion, by a factor of 44 , with strong impacts on natural resources. In 2019, 250 million in Africa and 234 million in SSA (or $20 \%$ of total population) were prone to chronic hunger. The problem is especially severe across six countries in East Africa (FAO et al. 2020).

Despite the great success in improving agronomic productivity since the onset of Green Revolution of the 1960s, food insecurity and malnutrition are perpetual problems in South Asia. The region also has the highest number of impoverished people (423 million), living on less than one dollar a day. South Asia also has the highest number of undernourished at 299 million. India's population of 1.34 billion is one-sixth of the world population, and it will be the most populous country of the world by 2025. India is home to $18 \%$ of the world population, and 194 million of these people are undernourished $(25 \%$ of the global population of hungry people). In addition, 47 million, or 4 out of 10 children, in India experience chronic undernutrition or starvation. By 2030, India will be the third largest consumer market, after the United States and China, and 90 million young people join the labor force every year. Nonetheless, access to nutrient-rich food, clean water, and a healthy, clean environment remains the foremost among major challenges. These challenges necessitate protection, restoration, and sustainable management of soil health.

Prevalence of undernutrition in India has decreased in percentage and absolute number from $23.7 \%$ and 210 million in 1990 to 1992 to $14.5 \%$ and 194 million in 2016 to 2018 (FAO et al.2020). However, opposite trends, both in percentage and absolute number of hunger-prevalence are observed in SSA where the percentage and absolute numbers are both increasing. It is precisely in this context that the importance of regenerative agriculture, the adoption of soil/crop/animal management practices that restore soil quality, cannot be overemphasized (Lal $2020 \mathrm{~b}$ ). These practices must be finetuned under site-specific conditions to enhance productivity and use efficiency of inputs. Therefore, the logical strategy is to better utilize the land already appropriated for agriculture to achieve its productive potential to the fullest extent and to return some agriculturally marginal lands back to nature.

Rattan Lal is a distinguished university professor of soil science and is director of the CFAES Rattan Lal Center for Carbon Management and Sequestration, the Ohio State University, Columbus, Ohio, United States.

Received June 7, 2021. 
Table 1

Global cropland area between 1961 and 2020 (World Bank 2021).

\begin{tabular}{|c|c|c|c|c|c|c|c|c|c|}
\hline Year & Population & \multicolumn{4}{|c|}{ Global land area $\left(10^{6} \mathrm{ha}\right)$} & \multicolumn{4}{|c|}{ Per capita land area (ha) } \\
\hline 1961 & 3.05 & 608 & 1,351 & 3,118 & 4,469 & 0.199 & 0.443 & 1.022 & 1.465 \\
\hline 1980 & 4.45 & 717 & 1,421 & 3,245 & 4,666 & 0.161 & 0.319 & 0.729 & 1.048 \\
\hline 1990 & 5.28 & 708 & 1,486 & 3,312 & 4,798 & 0.134 & 0.281 & 0.627 & 0.908 \\
\hline 2010 & 6.93 & 723 & 1,520 & 3,301 & 4,821 & 0.104 & 0.219 & 0.476 & 0.695 \\
\hline 2015 & 7.36 & 786 & 1,551 & 3,223 & 4,774 & 0.107 & 0.211 & 0.438 & 0.649 \\
\hline 2017 & 7.55 & 729 & 1,568 & 3,247 & 4,815 & 0.096 & 0.208 & 0.430 & 0.638 \\
\hline 2018 & - & - & - & - & - & - & - & - & - \\
\hline 2019 & 7.67 & 727 & - & 3,234 & - & 0.094 & - & 0.422 & 0.628 \\
\hline
\end{tabular}

\section{PRINCIPLES OF REGENERATIVE AGRICULTURE TO SAVE SOME LAND FOR NATURE}

A synthesis of literature (Harwood 1983; Francis et al. 1986; Giller et al. 2021) indicates the following key principles of regenerative agriculture:

1. Enhance and sustain agronomic productivity and functionality by restoring soil health and soil organic carbon (C) stock

2. Adopt conservation agriculture, with mulch farming and cover cropping to minimize risks of accelerated soil erosion and water loss by surface runoff and evaporation

3. Improve environment-positive nutrient flow systems and soil forming processes

4. Strengthen disease-suppressive attributes of soils

5. Increase use efficiency and minimize application and dependence on chemicals

6. Adopt management options that improve system eco-efficiency

7. Encourage technologies that promote biological nitrogen fixation (BNF), nutrient cycling, integrated soil fertility management (ISFM), integrated water management (IWM), integrated pest management (IPM), and complex rotations

8. Minimize the risks of inputs of antibiotics into soil

9. Reduce food losses (to less than 10\%), create value addition, and increase shelf life of produce
10. Plan and implement a system-based approach that involves self-reliance at a local, regional, national, and global scale

11. Use low external inputs by highlighting the importance of biological structuring, biological sequencing, and integrative farm structuring

12. Increase biodiversity, both above and below ground, and spare land for nature

The Dust Bowl in the 1930s in the United States was a transformational experience for appreciation of the importance of soil and management of soil health at the level of the scientific, political, public, and private sectors. The COVID-19 pandemic of 2019 to 2021 is also a transformational experience for appreciation of the importance of a buffer between humanity and wildlife, outlining the need to spare and return some land back to nature. As much as one-fourth (Gibbs and Salmon 2015) to one-third (FAO and ITPS 2015; UN 2020) of world soils are degraded, and the rate of soil loss by erosion exceeds that of soil formation by an order of magnitude (Evans et al. 2020). These global crises (the pandemic, soil degradation, global warming, mass extinction of species) are the tipping points to bring about transformational change in agriculture and the food system processes.

Therefore, the precious and finite soil resources must be protected, managed, and restored so that some agriculturally marginal land is returned back to nature.

\section{STRATEGIES FOR RETURNING LAND BACK TO NATURE}

The food produced already is enough to feed the current and the future world population. Improving access to food by the growing and increasingly affluent world population may be prudently met by

1.increasing production from existing

land by narrowing the yield gap,

2. reducing food waste,

3.achieving replacement fertility rates of population in developing countries by 2050 ,

4. restoring degraded soils, and

5. altering dietary preferences in favor of plant-based sources.

These options are land-sparing technologies, and if planned and implemented judiciously, can return some land back to nature. Dietary preferences toward plantbased products are critical to reducing the land area under agriculture. The strategy is to decrease the area of land under cultivation and not to convert any new land from natural to agricultural ecosystems, thereby minimizing risks of altering hydrological and biogeochemical cycles. Such a strategy would lead to zero net land degradation and zero net deforestation. The focus must also be on urban agriculture, sky farming, and soil-less food production systems (e.g., aquaculture, aeroponics, and hydroponics). Adoption of regenerative and restorative agricultural practices, including permaculture (Glover et al. 2010), can decrease the 
use of chemicals and enhance biodiversity, but produce lower yields (Snapp et al. 2019). Therefore, reducing food waste is a critical component of the land-saving strategy.

Temporal changes in land use between 1961 and 2018 are shown in table 1. It is argued that humans can use land more efficiently if they would accept austere diets (van Oorschot et al. 2012; Terluin et al. 2013; Meier and Christen 2013; van Kernebeek et al. 2016) and reduce food waste. Bahadur et al. (2018) argued that the "only way to eat a nutritionally balanced diet, save land, and reduce greenhouse gas emissions is to consume and produce more fruits and vegetables as well as transition to diets higher in plant-based protein." With balanced diet, per capita agricultural land area of 0.25 ha $(0.6 \mathrm{ac})$ may be sufficient. Thus, population of 10 billion will need a total to $2.5 \times 10^{9} \mathrm{ha}\left(6.2 \times 10^{9} \mathrm{ac}\right)$. Therefore, half of the currently used $5 \times$ $10^{9} \mathrm{ha}\left(1.24 \times 10^{10} \mathrm{ac}\right)$, or $2.5 \times 10^{9} \mathrm{ha}(6.2$ $\left.\times 10^{9} \mathrm{ac}\right)$ can be returned back to nature by 2100 , if not by 2050 . Realizing that this is an aspirational goal, it is in need of an attention by the United Nations Food Systems Summit in September of 2021 and the United Nations Climate Change Conference (COP 26) in November of 2021. There is an urgent need to outline the roadmap to achieve this goal.

\section{CONCLUSIONS}

The right to a "safe, nutritious, and adequate amount of food" for human wellbeing must be objectively and critically reconciled with the need to restore soil functionality and improve the environment. In this context, the excessive and indiscriminate use of fertilizers, pesticides, tillage, and irrigation can never be justified. The prudent and discriminate use of these inputs is critical. The conceptual basis of the adage of Paracelsus (1493 to 1541), "the dose differentiates a poison from a remedy" (Grandjean 2016), is more relevant to transforming modern agriculture now than ever before. In addition to improving soil health through adoption of nature-positive agriculture (Lal 2020a), improved varieties have and will play a significant role in enhancing and sustaining productivity (Lotz et al. 2020).
Regenerative agriculture, designed to restore soil health by creating a positive soil organic $\mathrm{C}$ and nutrient budget through adoption of site-specific and proven agricultural practices (e.g., conservation agriculture, agroforestry, complex rotations, integration of crops with trees and livestock, judicious use of BNF, ISFM, IWM, IPM), can offer the following global solutions:

1. Mitigate global warming by reducing emissions from agroecosystems and offsetting $15 \%$ to $20 \%$ of emissions from other sectors by sequestering atmospheric carbon dioxide $\left(\mathrm{CO}_{2}\right)$ in soil and wooded biomass and increasing its mean residence time

2. Restore and regenerate degraded soils of agroecosystems by enhancing soil organic matter content, improving soil structure, and optimizing soil physical, chemical, and biological properties

3. Promote nature-positive agricultural practices that narrow the yield gap, strengthen hydrological and biogeochemical cycling, and enhance eco-efficiency of external input and inherent resources

4. Increase multidimensional sustainability (economic, ecologic, social, and institutional) of agroecosystems by integrating modern innovations with the indigenous knowledge for creating site-specific innovative farming practices

5. Develop and create policy interventions and other mechanisms to reward farmers for provisioning of critical ecosystem services (e.g., sequestration of $\mathrm{C}$ in soil and biomass, improvement of water quality and renewability, strengthening of biodiversity, and creation of nutrition sensitive agriculture)

With these measures, along with prudent policies and education about soil management and dietary preferences, the aspirational goal of returning $2.5 \times 10^{9}$ ha $\left(6.2 \times 10^{9} \mathrm{ac}\right)$ of land to nature by 2100 and beyond can be realized.

\section{REFERENCES}

Bahadur, K.K., G.M. Dias, A. Veeramani, C.J. Swanton, D. Fraser, D. Steinke, E. Lee, H. Wittman, J.M. Farber, K. Dunfield, K. McCann, M. Anand, M. Campbell, N. Rooney, N.E. Raine,
R. Van Acker, R. Hanner, S. Pascoal, S. Sharif, T.G. Benton, and E.D.G. Fraser. 2018. When too much isn't enough: Does current food production meet global nutritional needs? PLOS ONE 13(10): $\mathrm{e} 0205683$.

Evans, D.L., J.N. Quinton, J.A.C. Davies, J. Zhao, and G. Govers. 2020. Soil lifespans and how they can be extended by land use and management change. Environmental Research Letters 15(2020):0940b2.

FAO, IFAD, UNICEF, WFP, and WHO (Food and Agriculture Organization of the United Nations, International Fund for Agricultural Development, United Nations Children's Fund, World Food Program, and World Health Organization). 2020. Transforming food systems for affordable healthy diets. In The State of Food Security and Nutrition in the World. Rome: FAO.

FAO, and ITPS (Food and Agriculture Organization of the United Nations and Intergovernmental Technical Panel on Soils). 2015. Status of the World Soil Resources (SWSR) - Technical Summary. Rome, Italy: FAO.

Francis, C.A., R.R. Harwood, and J.F. Parr. 1986. The potential for regenerative agriculture in the developing world. American Journal of Alternative Agriculture 1(2):65-74.

Gibbs, H.K., and J.M. Salmon. 2015, February. Mapping the world's degraded lands. Applied Geography 57:12-21.

Giller, K.E., R. Hijbeek, J.A. Andersson, and J. Sumberg. 2021. Regenerative agriculture: An agronomic perspective. Outlook on Agriculture (March 2, 2021):0030727021998063.

Glover, J.D., J.P. Reganold, L.W. Bell, J. Borevitz, E.C. Brummer, E.S. Buckler, C.M. Cox, T.S. Cox, T.E. Crews, S.W. Culman, L.R. DeHaan, D. Eriksson, B.S. Gill, J. Holland, F. Hu, B.S. Hulke, A.M.H. Ibrahim, W. Jackson, S.S. Jones, S.C. Murray, A.H. Paterson, E. Ploschuk, E.J. Sacks, S. Snapp, D. Tao, D.L. Van Tassel, L.J. Wade, D.L. Wyse, and Y. Xu. 2010. Increased food and ecosystem security via perennial grains. Science 328(5986):1638-1639.

Grandjean, P. 2016. Paracelsus revisited: The dose concept in a complex world. Basic \& Clinical Pharmacology \& Toxicology 119(2):126-132.

Harwood, R.R. 1983. International overview of regenerative agriculture. In Resource-Efficient Farming Methods for Tanzania. Emmaus, PA: Rodale Press.

van Kernebeek, H.R.J., S.J. Oosting, M.K. Van Ittersum, P. Bikker, and I.J.M. De Boer. 2016. Saving land to feed a growing population: Consequences for consumption of crop and live- 
stock products. The International Journal of Life Cycle Assessment 21(5):677-687.

Knoema. 2021. World Data Atlas. https://knoema. com/atlas/topics/Land-Use.

Laishram, R. 2020. 2020 Global Food Policy Report: Emerging challenges of building inclusive food systems in South Asia. Washington, DC: International Food Policy Research Institute. https://www.ifpri.org/blog/2020-global-foodpolicy-report-emerging-challenges-buildinginclusive-food-systems-south-asia.

Lal, R. 2020a. Home gardening and urban agriculture for advancing food and nutritional security in response to the COVID-19 pandemic. Food Security 12(2020):871-876.

Lal, R. 2020b. Regenerative agriculture for food and climate. Journal of Soil and Water Conservation 75(5):123A-124A. https://doi.org/10.2489/ jswc.2020.0620A.

Lotz, L. A. P., C. C. M. van de Wiel, and M. J. M. Smulders. 2020. Genetic engineering at the heart of agroecology. Outlook on Agriculture 49(1):21-28.

Meier, T., and O. Christen. 2013. Environmental impacts of dietary recommendations and dietary styles: Germany as an example. Environmental Science \& Technology 47(2):877-888.

van Oorschot, M., T. Rood, E. Vixseboxse, H. Wilting, and S. van der Esch. 2012. De voetafdruk van Nederland: hoe groot en hoe diep? (The footprint of the Netherlands: how big and how deep?). Den Haag: Planbureau voor de Leefomgeving (PBL).

Ramankutty, N., Z. Mehrabi, K. Waha, L. Jarvis, C. Kremen, M. Herrero, and L.H. Rieseberg. 2018. Trends in global agricultural land use: Implications for environmental health and food security. Annual Review of Plant Biology 69(1):789-815.

Ranganathan, J., R. Waite, T. Searchinger, and C. Hanson. 2018. How to sustainably feed 10 billion people by 2050, in 21 charts. Washington, DC: The World Resources Institute.

Snapp, S., P. Rogé, P. Okori, R. Chikowo, B. Peter, and J. Messina. 2019. Perennial grains for Africa: Possibility or pipedream? Experimental Agriculture 55(2):251-272.

Terluin, I.J., B.M. Kamphuis, D.A. Oudendag, and M.G.A. van Leeuwen. 2013. Voedselvoorziening in Nederland onder buitengewone crisisomstandigheden (Food supply in the Netherlands under extraordinary crisis conditions). Den Haag: LEI INT POLICY - Agricultural.

UN (United Nations). 2019. 2019 Revision of World Population Prospects. https://population.un.org/wpp/.

UN. 2020. United Nations Summit on Biodiversity. New York, NY: General Assembly of the United Nations.

World Bank. 2021. Data: Arable land (hectares per person). https://data.worldbank.org/indicator/ AG.LND.ARBL.HA.PC. 